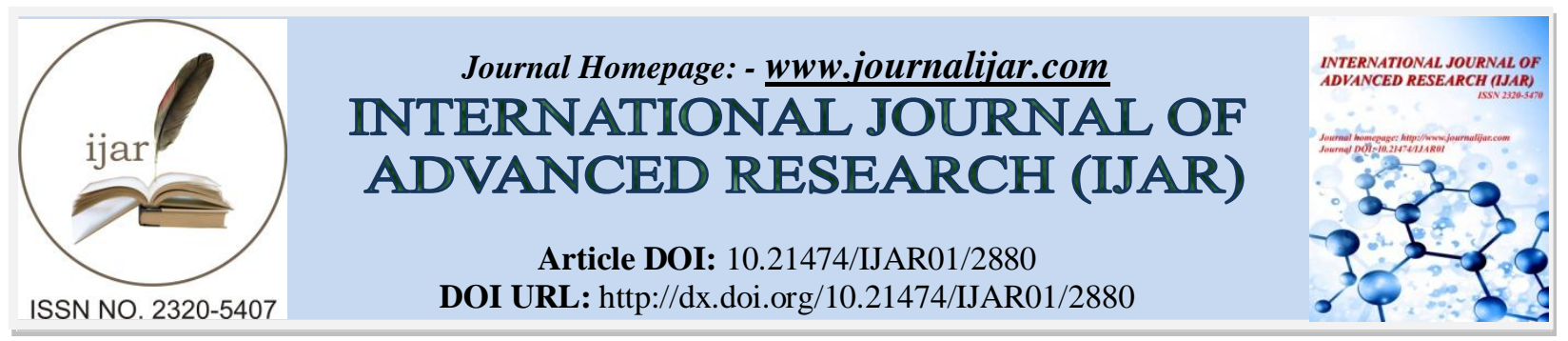

RESEARCH ARTICLE

\title{
NARRATING THINGS FALL APART THROUGH THE PRISM OF LANGUAGE
}

\section{Kshetrimayum Momo and Dr. Sangeeta Laishram}

1. PhD Scholar (English), Department of Humanities and Social and Sciences, National Institute of Technology Manipur.

2. Assistant Professor (English), Department of Humanities and Social and Sciences, National Institute of Technology Manipur.

\section{Manuscript Info}

Manuscript History

Received: 21 November 2016

Final Accepted: 21 December 2016

Published: January 2017

Key words:-

Igbo society, language, native narrative,

African identity, postcolonial

complexities.

\section{Abstract}

The present article studies Chinua Achebe's style of language used in his literary works that have helped shape the outcome of his native Igbo language as well as that of the English language. Since, Achebe has chosen the written word over the spoken as medium of linguistic and social reform, the analysis rest on the close reading of his magnum opus novel Things Fall Apart (1958) rather than perusal of his oral statements. Whereas his writings have catapulted him into a transcendental position in both the Western and African literary canons, his use of English language as his medium of expression has earned him much criticism from his fellow writers and critics alike. The paper has shown how well his narrative style is appreciated by both European and African readers.

Copy Right, IJAR, 2016,. All rights reserved.

"Until the lions produce their own historians, the story of the hunt will glorify only the hunter." Chinua Achebe, Home and Exile:-

Born on the $15^{\text {th }}$ of November in Ogidi in Eastern Nigeria, Chinua Achebe became one of the foremost authors of Africa of the twenty-first century. The author himself wrote of the time and place in which he was born and raised as "a strongly multiethnic, multilingual, multi-religious, somewhat chaotic colonial situation". (Achebe 39) In fact, Eastern Nigeria consists of many provinces that make up Igboland, dominated by the Igbo tribes of which Achebe's native town is one. Traditional Igbo societies are relatively autonomous and free from interference from other societies. The Igbo's pride themselves in their self governance and freedom from outside interference, which is their ideal aim in both the pre and post colonization period. Critics of the Igbo tribe have often claimed that they are a stateless or acephalous nation and their administrators have called them argumentative. The relationship of the Igbos with their British administrators has been tumultuous and complicated to say the least.

The infinity of possibilities that language exhibits enables it to capture the adaptability of man and prove that language is essentially an intricate form of expression that is in a constant state of metamorphosis. Cultures around the world change with the change of individual choices; language, being a part of culture, too changes with the change of culture.

The potency of a language is determined by its speakers. The evolution of a language is traced by the study of its native speakers and how they communicate within their communities. Linguist Steven Pinker argues that 
communication is "rooted in our development as individuals, but also in the history of our language community." (24) The present article is a study of one such speaker, Chinua Achebe, whose decisions about his language have helped shape the outcome of his native Igbo language as well as that of the English language. Since, Achebe has chosen the written word over the spoken as medium of linguistic and social reform, the analysis will rest on the close reading of one of his written text rather than perusal of his oral statements.

Achebe displays a sense of fearlessness in the statement of his purpose and an intention to deliberately engage his culture and international audience alike. It was with this determination that he wrote his first novel, Things Fall Apart (1958), with an aim to subvert and disrupt the prevailing notions of African servitude. He stated in reference to A Man of the People,

I wanted the novel to be a denunciation of the kind of independence we were experiencing in postcolonial Nigeria and many other countries in the 1960s, and I intended it to scare my countrymen into good behavior with a frightening cautionary tale. (Achebe 43)

The purpose of his writings is to shake up his audiences and countrymen with his voice before he allows them to sink into general apathy or stupidity.

The overwhelming success of Things Fall Apart has earned Achebe both acclaim and criticism. Whereas his writings have catapulted him into a transcendental position in both the Western and African literary canons, his use of English language as his medium of expression has earned him much criticism from his fellow writers and critics alike. As far as the novel is concerned, critics have invariably agreed that the novel describes "the effect of British missionaries and administrators on a typical village tribal society; the dislocation that change, religious and educational, brings to historic certainties" (Povey 254), and that it does so with a "tragic objectivity". (Ravenscroft 9) The novel is greatly admired by its readers for its realistic depiction of Igboland, its rich symbolism, metaphor, imagery and the lessons it teaches about community and the convergence of cultures. Despite of using the usurping British tongue, Achebe successfully betrays a wholly African perspective on the English novels retains a leitmotif of African tribalism and betrays his multilingual abilities through an extensive use of the Igbo vocabulary.

Achebe's decision use the hegemonic British tongue to espouse the native narrative has led to questions over his allegiance to his homeland and his beliefs about colonialism. Ngugi Wa Thiong'O's disappointment with the African acceptance of English is discernible when he writes that "it is the final triumph of a system of domination when the dominated start singing its virtues." (20) For Ngugi, Achebe's choice of language was a loss of the African identity and culture. But, it would go without saying that Achebe's Things Fall Apart proves Ngugi's concerns as unfounded and that an African writer can retain his culture and belief while still writing in English for practical purposes.

In Home and Exile, Achebe makes a powerful statement, "until the lions produce their own historians, the story of the hunt will glorify only the hunter." (73) The statement is an embodiment of Achebe's life and works and the force that drives his conscious and subconscious language attitudes. Achebe is a historian, albeit self-elected. He is the narrator of the Igbos in particular and the Africans in general, narrating the story of the lion in the language of the hunter. It is quite sure that Achebe knew the risks of writing in the English language but despite this, he wrote Things Fall Apart with an intention to allow the western reader to be a partaker as well as a reveler in the African language and lifestyle. What follows is Achebe's use of language to achieve his aim.

Chinua Achebe succeeds in using the narrator as the most potent tool to express African identity and reality in Things Fall Apart. In fact, Achebe's concern as an African writer was the proper representation of Africa and its people. Achebe was very critical of Joseph Conrad and his depiction of the African nation and its people, so much so that he even called Conrad "a bloody racist". (Achebe 328) Achebe accused Conrad of choosing "the role of purveyor of comforting myths". (325) According to him, Joseph Conrad had rather enforced the European stereotypes that existed in the early twentieth century rather than representing Africa and its people in an appropriate manner. Things Fall Apart is the result of Achebe's will to counter Joseph Conrad's Heart of Darkness and to write a story that appropriately reflects his country, tribe and his people. The omniscient narrator is responsible for bringing the novel to life in Things Fall Apart, and by doing so in an objective manner. He encourages the readers of the novel to come to their own opinions about the African story. 
The narrator is the chronicler of the disintegrating Igbo society and as such he is an insider of the Igbo community, omniscient but objective. Achebe allows the narrator to reveal his own personal observations about the Igbo way of life and their traditions and customs. The status of the narrator as an insider is revealed right from the outset of the novel as he captures the rise to fame of Okwonko as well as the physical changes that he has undergone in a span of twenty years, "that was many years ago, twenty years or more, and during this time Okwonko's fame had grown like a bushfire in harmattan. He was tall and huge, and his bushy eyebrows and wide nose gave him a very severe look." (Achebe 3) Such an intimate observation can only be given by an insider who is familiar with the characters involved. The narrator of the novel is established as a reliable spokesperson for Okwonko and his tribesman by virtue of his familiarity with the tribe and its people [characters].

The distinctly African style of narrative that the narrator used to detail the food and religion of the Igbo community and its tradition further confirms his native stature. The details of about yam foo foo as being the chief food in celebrations allow the readers to envisage a realistic African ritual:

yam foo foo and vegetable soup was the chief food in the celebration. So much of it was cooked that, no matter how heavily the family ate or how many friends and relations they invited from neighboring villages, there was always a huge quantity of food left over at the end of the day. The story was always told of a wealthy man who set before his guests a mound of foo-foo so high that those who sat on one side could not see what was happening on the other, and it was not until late in the evening that one of them saw for the first time his in-law who had arrived during the course of the meal and had fallen to on the opposite side. (Achebe 23)

The African's appreciation for words, metaphor and figurative language is reflected in this passage. Oral traditions are distinctive tribal characteristics through which the history of the tribe is passed down the generations. In this passage, Achebe captures the importance of the oral tradition in the Igbo society. The narrator is the mouthpiece of the author who speaks as a wise sage would speak to his young pupils and teaching them of the significance of food and relationships within the community.

The discussion of the narrator's power is not complete without giving him credit for the use of gender-specific language. The feminine language in the novel enters with Okonkwo's wives and Ezinma, his daughter. The narrator addresses the heavy handed treatment of his wives by Okonkwo at first, but his voice become softer when he describes Okonkwo's favorite wife Ekwefi or her daughter Ezinma. The readers are taken by surprise when Okonkwo displays an unusual sympathy and follows his wife and daughter to the oracle's cave. This episode is only one of a few verbal repartees between Okonkwo and his wife and the narrator captures it as:

Tears of gratitude filled her eyes. She knew her daughter was safe. "Go home and sleep," said Okonkwo. "I shall wait here."

"I shall wait too. It is almost dawn. The first cock has crowed."

As they stood there together, Ekwefi's mind went back to the days when they were young. She had married Anene because Okonkwo was too poor then to marry. Two years after her marriage to Anene she could bear it no longer and she ran away to Okonkwo. (65)

In the passage above, the voice of the narrator captures an intimate display of vulnerability and the African humanity that twentieth century Europeans have never seen before. The passage above reveals the trust that Ekwefi has for her husband as well as the passionate bond that they share. Two years earlier, Ekwefi had trusted Okonkwo with her life and sexuality, now, she trusts him with the life of her daughter. This dialogue between the two is the only time in the novel that captures the soft side of Okwonko. The rough Okwonko is never harsh to Ekwefi, the wife he loves and never tries to prove his strength or show off his warrior like attitude. To Ekwefi, Okwonko is simply a man, a loving husband, a caring father who wishes to protect his daughter. He not only pursues his wife and tries to persuade her to return home to safety, but also allows her to defy him and stay by his side, a similar act of defiance that once brought a beating to Ojiugo but now encourages respect for Ekwefi.

Okonkwo's intimacy to Ezinma is further extended in the later part of the novel when they begin to interact more at home. The narrator not only captures Okonkwo's concern for his daughter but also shows the value that he places on her daughter as an individual. Okonkwo has a soft spot for his daughter. The narrator states that Ezinma matures in beauty and character during Okonkwo's seven years of exile. She begins to receive the attention of men in Mbanta and this makes Okonkwo sad because "he never stopped regretting that Ezinma was a girl. Of all his children she 
alone understood his every mood. A bond of sympathy had grown between them as the years had passed." (98) This vulnerability of Okonkwo lets us readers take a deeper look into the softer side of the protagonist, a side that only the narrator is privy to. The humanity of the African culture is vividly captured by the narrator and successfully establishes the African citizens as a people with a voice.

The duality of the voices and the role of the narrator is a perplexing conundrum for many scholars. In the postmodern world, the role of the writer is doubted and questioned resulting in many critics rejecting this ethnographic narrator with ties to the author. A postmodernist would reject Achebe's reflection in his work and contend that the narrative devices are established accidentally or a result of unintentional language use. It will take Cary Synder, the literary critic to counter this dilemma, arguing that the shifting narrator "from the most credulous believer to the skeptic or cultural outsider... replicates the dynamic positioning of the native anthropologist - at once part of Igbo culture and apart from it"(168). The language of Achebe should not be equated with the author by the readers of Things Fall Apart and should give room for the acceptance of authorial intention on the grounds of an anthropological agenda. It must be accepted that Achebe is an insider and can depict the life and culture of Igboland with authority; it should also be accepted that Achebe, as an author, skillfully crafts the Nigerian world with objectivity and grace through his particular narrative devices.

The narrator plays a prominent role in understanding Things Fall Apart and the African image that the novel portrays. The absence of the narrator will probably lead to two undesirable positions, either Achebe would have to write from a more personal point of view and risk being esoteric and alienate his European audience, or, the novel could have taken a more objectified and critical perspective which Achebe desperately wants to Conrad, the criticalness of his contemporary Conrad. The purpose of the novel is to portray the African as a relatable and human entity. The narrator provides Achebe with the tool that he needs to construct an artistic, objective and delicate style of writing. The narrator's familiarity of the Igbo society and his ability to look into the thoughts and actions of the characters makes him the author's tool of choice.

'Achebe's intention to create a new African image is manifested in his use of narrative devices. The objectivity of the narrator's language enables him to capture the events of the plot and the hidden observation of the characters. Achebe's skill of using an objective narrator is praised by Hilary Dannenberg as:

It is Achebe's ability to endow his narrative with a post-binary and thus a truly postcolonial complexity which lies at the heart of the groundbreaking nature of Things Fall Apart. Achebe's narrator is so nimble and mercurial that he subverts all binaries. This narratorial and ideological mercuriality is achieved through the inclusion of many layers of voice, perspective and culture in the text. (176)

The most important term in this quote is "postcolonial complexity." Achebe does not intend to solve the problems in his linguistic spectrum. He offers no solutions; he only depicts the torrid state of affairs with simplicity and realism. It is this focused and detailed description that allows European and African readers to appreciate his narrative style.

\section{References:-}

1. Achebe, Chinua. (2009). A Man of People. London: Heinemann. Print.

2. ---. (2000) Home and Exile. New York: Oxford Up. Print.

3. ---. (2009). The Education of a British-Protected Child. New York: Random House. Print.

4. ---. (2009). Things Fall Apart. Ed. Abiola Irele. New York: Norton. Print.

5. Conrad, Joseph. (2004). Heart of Darkness. New Delhi: Worldview Publication. Print.

6. Dannenberg, Hilary. (2009).“The Many Voices of Things Fall Apart." In Interventions: International Journal of Postcolonial Studies 11.2: 176-79. JSTOR. Web. 15 May 2015

7. Pinker, Steven. (2007). The Stuff of Thought: Language as a Window into Human Nature. London: Viking Penguin Group. Print.

8. Povey, John. (1966). "Contemporary West African Writing in English.” In Books Abroad 40.3: 253-260. JSTOR. Web. 15 May 2015.

9. Ravenscroft, Arthur. (1969). Chinua Achebe. London: F. Mildner and Sons. Print.

10. Snyder, Carey. (2008). "The Possibilities and Pitfalls of Ethnographic Readings: Narrative Complexity in Things Fall Apart." In College Literature 35.2: 154-74. Web. Academic Search Complete. 15 May 2015.

11. Wa Thiong'o, Ngugi. (1986). Decolonising the Mind. New Hampshire: Reed Publishing Inc. Print. 